\title{
Critical Theory and Transformative Learning: Some Insights
}

\section{Introduction}

The purpose of this article is neither to study critical theory in a contemporary perspective nor to present an analysis of Mezirow's critical reflection within transformative learning. It is rather a consideration of critical theory alongside transformative learning. By discussing these two theories together that are fundamental to adult education, we highlight how they overlap and their unique characteristics, and subsequently, probe connections and possibilities within adult educational settings. The literature landscape of critical theory and transformative learning is vast, but both theories remain, or at least should remain 'under construction', and despite the discussion surrounding them there is still much thinking to be done. The present paper is our attempt to contribute further thought to the scholarship of critical theory and transformational learning and to stimulate further thinking about these two seminal theories. We begin with a discussion of critical theory and transformative learning before turning attention to considerations for incorporating transformational learning and critical theory to frame educational activity.

\section{Critical theory}

The fundamental tenet of critical theory is that knowledge cannot be separated from the agents of the system in which it exists - all knowledge is shaped by the interests of various people and systems (Author, 2015). The aim of critical theory is to "make problematic what is taken for granted in culture" for the purpose of "social justice," to the benefit of "those who are oppressed" (Nichols \& Allen-Brown, 1996, p. 226). In making problematic what is taken for granted, critical theory as a theoretical orientation acknowledges power imbalances and represents a dialectic 
methodology, which requires back-and-forth interaction between individuals who demonstrate mutual respect for the diverse insights each person contributes (Bradley-Levine \& Carr, 2015). Bradley-Levine and Carr (2015) point out, "The call to work for social justice embedded in critical theory aligns with a similar vocation rooted in Catholic social teaching (CST)" (p. 29). They go on to say, "those who work within institutions, such as education researchers, are called to work for systemic changes that will create more just institutions" (p. 29). Some Catholic teachings, which focus on concern for the poor and oppressed, elimination of repressive situations and structures, acknowledgement of the dignity of life, and encouragement to care for family and community, underscore the necessity for solidarity and a focus on a global world where the human condition is shared (Bradley-Levine \& Carr, 2005). Bradley-Levine and Carr (2015) explain it is important to recognize how “one person's actions have the potential to affect others in positive and negative ways, and where individuals have a responsibility to respond to the needs of others - especially those who have been marginalized by oppressive situations, institutions, policies, histories, and so forth" (Bradley-Levine \& Carr, 2015, p. 30).

In adult education, critical theory is particularly pertinent, because as mature individuals, we are surrounded not only by developmental tasks and life problems, but also personal and institutional ideologies, hegemonic practices, inequality, bigotry and alienation. As Rousseau observed, "Man is born free, but everywhere he is in chains" (Deneys-Tunney, 2012). From the moment of birth, interactions with others commence and the experiences of interacting with those around us shape the development of our attitudes, values and beliefs. Many of our adult assumptions about reality are formed or at least have significant roots in the years of our development, and unfortunately, those assumptions tend to remain unquestioned as status quo. 
Mezirow (1990) poignantly states, that re-assessment of the assumptions gained in the developmental years should be critically re-examined during adulthood.

As advanced by theorists such as Adorno (1973), Horkheimer (1974, 1995), Marcuse (1964) and Brookfield (2005), critical thinking is central to understanding and framing critical theory. "Critical thinking is about individuals disengaging from the tacit assumptions of discursive practices and power relations in order to exert more conscious control over their everyday lives" (Brookfield, 2005, p. 12). According to Gaudelli (2008), critical theory is built around crisis pedagogy, which creates dissonance within learners for the purpose of influencing them to rethink their assumptions and liberate them from anxiety, fear, and defensive actions. This allows them to embrace their roles as change agents and engage in critical reflection. Critical reflection is an indispensable part of the critical thinking process and "springs from an affirmation of human capacity to think deeply and carefully" (Gaudelli, 2008, p. 76). It must be noted here that making an assessment of assumptions is not implicit to reflection or even to critical reflection. "Reflection” states Mezirow (1998), "does not necessarily imply making an assessment of what is being reflected upon...[and] critical reflection may be either implicit, as when we mindlessly choose between good and evil because of our assimilated values, or explicit, as when we bring the process of choice into awareness to examine and assess the reasons for making a choice" (p. 186).

It is through explicit critical reflection that individuals question their beliefs and assumptions, and all those 'norm and values,' that on the surface at least, appear accurate, obviously correct and morally good. In other words, explicit critical reflection may manifest as critiquing one's ideology. Within individuals, groups or subgroup cultures, there exists to varying degrees ideological conformity. This ideological conformity subtly influences thought 
and the development of attitudes, values, actions, and behaviors of individuals through to adulthood (Brookfield, Kalliath, \& Laiken, 2006). Thus, ideological critique, as explained by Brookfield (2001), is an essential element of critical theory:

Critical theory views ideologies as broadly accepted sets of values, beliefs, myths, explanations, and justifications that appear self-evidently true, empirically accurate, personally relevant, and morally desirable to a majority of the populace, but that actually work to maintain an unjust social and political order. (p. 14)

Brookfield (2005) furthers his explanation of critical theory, describing three core assumptions that frame how people perceive the world. First, that although Western democracies appear to be egalitarian, they actually support "economic inequity, racism, and class discrimination (p. viii). Second, that these inequities are reproduced through the "dissemination of dominant ideology" (p. viii), and finally, that "critical theory attempts to understand this state of affairs as a necessary prelude to changing it" (p. vii). Cranton and Taylor (2012) contend that dominant ideology "perpetuates itself - it is seen to be the normal way to think and act" (p. 7) and thus continues, unexamined and unchallenged.

Critical theory, with its core of questioning assumptions, challenging established worldviews and critiquing ideologies is not merely desirable, but strongly necessary in education today. To illustrate why it is essential, consider the case of social media. It is commonly stated that social media is a tool facilitating open communication and greatly increases knowledge sharing. However, as Gibbs, Rozaidi and Eisenberg's (2013) research in the field of organizational knowledge sharing reveals, communication and knowledge sharing via social media is far from being open. Rather, individuals in the organization use social media 
strategically, protecting or restricting the flow and type of information to serve the needs of various organizational and strategic goals (Gibbs, Rozaidi, \& Eisenberg, 2013).

Literature surrounding social media is characterized by an "ideology of openness" since much of the literature "overstates the positive impacts of social media and assumes open communication is always desirable", but as exposed by Gibbs, Rozidi and Eisenberg (2013) this vision of social media is not accurate. The reality of social media flow of information is far from the Utopian view of unrestricted, free flow and access (Gibbs, Rozidi, \& Eisenberg, 2013). Another example of the unquestioning acceptance of news is the Russian influence in the form of "bots" and fabricated news links evident on Facebook during the US 2016 election cycle (https://www.nytimes.com/2017/10/30/technology/facebook-google-russia.html).

Ideology critique, as a learning process, describes the ways in which people learn to recognize how uncritically accepted, falsely true, and sometimes unjust dominant ideologies are embedded in everyday situations and practices. As an educational activity, ideology critique focuses on helping people come to an awareness of how they have been shaped by the perspectives they hold, often without their knowledge, and belief systems and assumptions (that is, ideologies) that justify and maintain the status quo. But raising awareness of the nature of blindly held, unquestioned assumptions is only part of the journey towards the ideals of empowerment and liberation. Transformative learning assists adults through a "process of examining, questioning, and revising" (Cranton \& Taylor, 2012, p. 5) their assumptions and perceptions about their experiences, which may lead changed understandings and world views.

\section{Transformative Learning Theory}

Learning from the perspective of critical theory is the "process of challenging truth claims and arriving at a critical consciousness that these are not universal truths but claims that 
serve the interests of some at the expense of others" (Kilgore, 2001, p. 59). From the perspective of transformative learning theory learning is deep and involves a change in perspective. The essence of critical theory is raising consciousness and awareness, but the essence of transformative learning is deep-seated change in the core of individual perspectives and worldviews that ultimately shapes activity and behavior.

The essence of how learning occurs viewed through transformative learning theory and critical theory frameworks is somewhat different, however, there is an obvious and well-argued relationship between critical theory and transformative learning. If the key tenet of transformative learning theory can be captured in one brief phrase then it is not what we know but how we know that is important (Baumgartner, 2001). Transformative learning goes beyond evaluation and awareness of existing assumptions to a change or transformation in perspective. Transformation in perspective permeates at the deepest level of self, so that our behaviors and world view are fundamentally different than pre-transformation. As we bring together critical and transformative learning theories, it surfaces clearly that while critical theory demands that individuals become aware of assumptions and taken for granted assumptions that may serve to disempower, mere recognition of the conditions causing oppression or understanding certain people as unequal is fruitless unless some action is taken that ultimately creates transformation for the benefit of all. Hence, Mezirow (1981) applies critical theory to transformative learning. According to Mezirow (1998), the critical reflection leading to transformative learning is founded on the standards of rationality and discourse, and critical thinking is thus "principled thinking; ideally, it is impartial, consistent and non-arbitrary" (p. 186). It is noteworthy that Mezirow (as distinct from Freire) does not conceive of transformative learning as always and necessarily leading to social emancipatory action. Instead, Mezirow was "primarily interested in 
the perspective of the individual engaged in transformative learning" (Cranton \& Taylor, 2012, p. 7).

Though transformative learning is reliant on critical thinking, it should be said that critical thinking is a necessary, but not sufficient condition for transformative learning. It is the socially constructed experiences that form the launching point for transformative learning (Mezirow, 1995). Thus transformative learning is situated in a framework of experiential learning, and Mezirow developed transformative learning theory through a constructivist framework (1991). It is partly for this reason that transformative learning through servicelearning projects represents an approach holding the potential to reformulate perspectives as adult learners face challenging issues and work to resolve them (Bamber \& Hankin, 2011).

Service learning projects. Following Mezirow's concepts, the commonly held opinion in literature is that service learning generates a level of "disequilibrium or anxiety and a heightened urgency to learn" that is conducive to deeper, more meaningful and relevant learning (Hullender, Hinck, Wood-Nartker, Burton, \& Bowlby, 2015). When adult learners participate in service learning projects, they typically encounter complex problems that are not easily solved by relying on existing frames of reference or their current understanding of a situation. Even those individuals who may view themselves as experts in their field may find that while their edicts may go unquestioned in their own organizations, other organizational leaders working within different power structures may not be as willing to follow their recommendations or suggestions without input. Others may find it interesting that while they may be ignored or overlooked in familiar settings, in the classroom or consulting setting, their insights may be valued and appreciated in their service learning contexts. Positive learning outcomes rests on the individual's willingness and capability to respond positively to the state of disequilibrium. From 
this perspective, it becomes clear that as educational activity, the goal of education encompasses activity, which equips individuals to achieve positive outcomes from their experiences.

Reflective practice. Reflective practice, is as noted by Hullender et al. (2015) is an essential "conduit for transformative learning" (p. 61). The overlap between transformative learning and critical theory again crystallizes. Hullender et al. (2015) find that the individuals who were more likely to experience positive outcomes and transformational learning from their service learning experiences were those who demonstrated an awareness of perspectives other than their own, who were able to reach new conclusions having had a system in place for negotiation of new and different information; successful learners were able to "deconstruct their past perspectives, relate to their current identity, position and power"( p. 76) - these capabilities are at the center of learning within the domain of critical theory. Transformative learning then has its base in experience and the ensuing critical thinking and reflection encouraged by critical theory.

Transformative learning approaches require teachers and facilitators to go beyond information giving and dissemination of facts; and, it involves more than being sensitive and socially relatable because neither dispositional orientation towards students is transformative or genuinely student-centered with a holistic perspective (Rosebrough \& Leverett, 2011). Transformative teaching requires a balance of support and challenge (Cranton, 2002). Cranton (2016) argues that transformative learning is voluntary and somewhat self-directed and experiential because only the individual can choose to engage in critical reflection regarding deeply held beliefs and question his or her personal values. However, educators can provide the space and activities that may engender the critical reflection necessary for transformative learning. 


\section{Honesty, safety, trust and transformation}

"Transformative learning .... does not happen in a vacuum, solely through the free will of an autonomous learner; rather, it is contextually bounded and influenced by relationships with others" (Taylor \& Snyder, 2012, p. 44). In the classroom, the dynamics of interaction with others and with the teacher are therefore significant determinants of how (if at all) participants will engage in transformative learning. Experience and critical thinking fuel transformative learning; thus it is important to consider the conditions in which such activity is most likely to thrive within educational contexts. Educational activity grounded in critical theory requires helping people to come to an awareness of existing assumptions and learning and helping to examine the how and why of such assumptions. Educators must be aware that providing opportunity for critical reflection or structuring activities designed to incite critical reflection is only part of their task; they must also nurture a conducive classroom climate.

Activities grounded in critical theory necessitate not only individual introspection but also understanding others; hence, there are two conditions conducive to critical thinking, reflection and transformative learning: first and foremost, there must be a climate of safety, and trust, and secondly, genuine and honest discussion and communication must take place. The introspection and evaluation through discourse required by critical theory can only take place when there is genuine dialogue and authentic communication. People involved in dialog need to be able to recognize genuine conversation with openness so they can learn through what should and should not be shared. "Discussions can be counterfeit; that is, they can seem on the surface to be entirely open, but in reality, someone with power in the group is steering the conversation to a predetermined conclusion" (Brookfield et al., 2006, p. 831). 
In many classrooms, as well as organizational environments, people do not feel safe enough to share their thoughts without fear of ridicule or ostracism, which often begins with individual conformity and then group tyranny, which perpetuates groupthink (Harvey, 1988). Through dialogical exchanges people can create narratives and stories that ease the pain of existential risk in sharing (Armitage, 2010; Harvey, 1988); yet Bohm and Peat (1991) note, "a spirit of goodwill and friendship is necessary for this to take place" (p. 82). People need to go beyond recognizing and talking about disparities and differences in perspectives in order for genuine change to occur; genuine change requires paradigmatic shifts through transformative learning.

It can be daunting to open conversations in a classroom around topics that will certainly bring forth diverse perspectives that are built upon deeply held beliefs and assumptions. Kincheloe (2008) argues to do so requires radical love and "the grounding of love" (p. 399) in the classroom. He states, "With radical love as our foundation, we can begin to listen anew to ideas whose meaning transcends the exact words uttered. We can begin to appreciate the words of those long excluded and whose contributions to justice and love were once relegated to the garbage heap of history" (Kincheloe, 2008, p. 399). Liston (2008) discusses the importance of attentive love and argues, "Only when struggled heartache delivers seasoned wisdom, will critical theory inform meaningful practice (pp. 387-388). He describes attentive love in teaching as "a struggle and a sacrifice. It is a struggle and a sacrifice to see beyond our egoistic selves so as to see our students more clearly" (p. 389).

Educators must know how to engage in difficult conversations in this way before they will be successful in guiding students to develop wisdom through critical reflection and dialog. Weil (2004) notes, "Human beings cannot solve problems collectively or individually if they do not know how to cooperate civilly" (p. 485). 
Openness to perspective transformation requires patience, kindness, courage, civility, and respect for self and others. Weil (2004) states,

Developing the courage to examine our beliefs, in light of what others believe, is often a difficult process for all of us. The courage to confront one's own irrational thinking becomes paramount and requires fortitude and strength. Similarly, having the courage to give a fair hearing to the assumptions, conclusions, claims, and beliefs of others is of paramount importance in assessing our own thinking. (p. 487)

In addition to courage and civility, adult learners need to develop integrity, perseverance, discipline, curiosity, imagination, responsibility, and tolerance for ambiguity, which represent values and dispositions necessary for critical thinking (Weil, 2004). Kincheloe (2004) contends, genuine critical thinking moves us beyond egocentrism and requires compassion and humility and argues, "Critical thinking then moves into the ontological realm since it helps us rethink who we are and what it means to be human" (Kincheloe, 2004, p. 28).

Being able to view a situation from multiple vantage points and new angles brings insights on the journey of dialogical engagement that can help people develop new ways of seeing and understanding a problem or situation. Noticing who benefits from a particular line of reasoning or ethos is another important step, and while some will be gratified with being in the majority on a particular issue, there will be those who feel oppressed or marginalized by the dominating viewpoint. Educators who can engage in critical thinking in this manner have the inner strength to listen to diverse perspectives and model the attitudes and behaviors they hope to develop among their adult learners. The hope of education is that through the process of 
perspective change and maturation, the influence upon the adult learners will reverberate throughout their families and communities and thus nudge systems into new patterns of relating that reform systems.

Learners must engage in a process of inquiry to gain deeper insights into unfamiliar challenges, including those that challenge personal identity; and, through this process, they have the opportunity to question what is familiar to gain new understanding of self and others (Bamber \& Hankin, 2011; Mezirow, 1991). Alongside a climate of trust, safety and honesty there must be a certain degree of 'readiness' to change. Adult learners who lack a readiness to change may avoid transformation of their perspectives in order to maintain an internal equilibrium where they feel safe and secure; paradoxically, those people who are open to change may initially "feel insecure and unsure" (Mezirow, 1978b, p. 101). Through critical reflection adult learners who demonstrate readiness to change are more likely to be the ones to "break with the taken-forgranted and set the familiar aside" (Greene, 1995, p. 3) in order to experience perspective change and transformative learning.

When educators are designing learning activities using critical thinking to facilitate transformative learning, mutual trust among the members of the learning community is important; otherwise, it will be challenging for group members to accommodate diverse perspectives. Ryman and Richardson (2010) explain, “Once a sense of community has formed between individual learners, a deeply transformational learning experience can be nurtured to enable new knowledge creation" (p. 46). It is imperative for educators to model the behavior they expect from students in terms of mutual trust and respect toward all members of the learning community. There is no room for negative evaluative judgment or dismissive attitudes toward any individual including other educators; once people begin to justify their poor treatment of one 
individual, they are no longer free from preset patterns of thinking and acting. Being conscious, both, individually and collectively, for moral disengagement among group members is necessary when participating in the work of perspective transformation. People have internal standards that delineate what is appropriate treatment of fellow human beings and what is inappropriate. Bandura (2002) explains, "People do not usually engage in harmful conduct until they have justified it to themselves" (p. 103). Awareness of tendencies for euphemistic labeling, advantageous comparison, displacement of responsibility, diffusion of responsibility, disregard or distortion of consequences, and dehumanization (Bandura, 2002) is necessary in social interactions and critical dialog around sensitive issues.

\section{Power}

Inevitably, in any discussion of trust, safety and honesty, a discussion of power also arises. Cranton and Taylor (2012) contend that "unmasking power involves recognizing how power is exercised in our own lives in everyday actions (p. 9). People in positions of power may have the most difficultly with allowing diverse perspectives to enter into a conversation because it means others who are lower on the hierarchical chain of command or socio-economic scale will question and examine their privileged or top down decisions and point out ways by which certain processes, policies, and practices oppress or marginalize them as mere workers, cogs in the wheel, rather than as genuine contributors or thinkers themselves. Brookfield (2005) describes this as "contesting hegemony". Overcoming defensiveness in hearing other perspectives is paramount for effective leadership, and truth be told, few have the capacity to genuinely lead or engage in transformative learning without educational guidance and friendship support because they may be more concerned with saving face, maintaining their status, protecting their impression on superiors or referent group members, and exerting unilateral 
control as the supreme authority figure. Such individuals will be mightily challenged to engage in genuine critical reflection, but they will be quite open to the idea of underlings engaging in critical reflection and transformative learning especially if they believe the process will further acculturate individuals through socialization in order to achieve conformity in thinking and adherence to the organizational mission. Others may be accustomed to silence because they believe their observations are less valuable than others, and they may be so habituated to withholding their comments that they need to be encouraged to share without being overly deferent to others. When adult learners engage in self-reflection with openness to perspective transformation, educators need to encourage them to focus on personal development first and foremost. In adult education, each individual will gain personal insights to the degree they choose to critically reflect on their deeply held assumptions.

Useful to a discussion of power in dialog is Buber's modes of dialogical communication. According to Buber (1958), there are two modes of dialogical communication, "I-It" and "IThou". When people view others as an "it", the person is regarded as an object to be maneuvered around, moved, used, or discarded. When people view others as a "thou", there is a sacred uniqueness to each person with immeasurable value. When adult educators attempt to facilitate transformative learning among students working together in groups, they need to encourage authentic communication within a safe place where each person is applauded and honored, where people express sympathetic and passionate concern for others and what they have experienced in life and how such influences their viewpoints (Cotton, 2017). Buber (1958) declared, “All real living is meeting" (p. 26). The I-Thou relation "is an encounter of equals who recognize each other as such" (Morgan \& Guilherme, 2012, p. 982). In contrast, Morgan and Guilherme (2012) 
explain, the I-It relationship is confrontational, objectifying and a failure to see the other as an equal.

\section{Educators as transformative learners}

Thus far, it is argued that as an educational activity, educators must establish a climate conducive to learners engaging in critical thinking, reflection and transformative learning. For educators, employing critical theory and transformative approaches it in itself a process of transformation. Hence, for those who are engaged in critical theory and transformative learning as educational activity, it is desirable, as Mezirow points out, that educators firstly engage in their own reflection to become critically aware of how and why the structure of psychological and cultural assumptions have come to constrain the way people see themselves, the society within which they live, and their relationships (p. 6). While Marx and Lenin looked to a change of the ruling class's ideologies through violence, Mezirow proposes that educators' teaching strategies can potentially change through their critically reflecting upon them. As Brookfield (2005) emphasizes, perspective change is not possible without ideology critique. Educators are themselves learners - learners about teaching practices and best learning contexts, and critical theory is about challenging truth and arriving at a critical consciousness (Kilgore, 2001, p. 59). Thus, educators can change the way they learn about teaching practice through an understanding of critical theory. It is when educators are truly engaged in emancipatory learning that changes in practice occurs. Emancipatory learning is not easy, and although many may claim it is as a goal, it is an ongoing process. Emancipatory learning for educators requires a reexamination of their teaching practices through a critical lens, rather than simply relying on the more traditional and possibly passive teaching modes to guide their practice. Ultimately, educators will need to experience critical introspection on their philosophical beliefs upon which their teaching practice 
rests. Since teaching is inextricably linked to learning, as educators engage in critical introspection of their own beliefs, critical theory may well color the nature of the teaching strategies they devise.

A critical theory approach to teaching and learning is a transformative endeavor that is exploratory, requires empowerment, and encourages inquiry to confront injustices as a pathway to change social systems, policies, and processes (Denzin \& Lincoln, 2011; Kincheloe, McLaren, \& Steinberge, 2011; Watson \& Watson, 2011). Traditional theory in the natural sciences strictly separates thought and action with a focus on developing generalizations about the world, thereby objectifying reality; through prediction and control, scientists attempt to understand human nature through the use of the scientific method. Critical theory goes beyond traditional, positivistic approaches to explain human nature and learning through interpretative approaches (Watson \& Watson, 2011). Watson and Watson (2011) explain the use of traditional scientific approaches are not suitable in the social sciences because when used singularly they result in "reductionist, inaccurate, and unsuitable approaches to solving social system problems" (p. 65). Critical theory in the social sciences is reflective, aims at producing enlightenment, and is inherently emancipatory (Carr, 2005; Geuss, 1981; Horkheimerm, 1976). Carr argues, "our world is a mediated world" (p. 483), which underscores the notion that people and systems are interconnected and together influence the construction of knowledge.

\section{Tensions and dangers}

From an idealist perspective, the notions behind critical theory and transformative learning theory are highly desirable. Approaches founded on the two theories have the potential to better the human condition by exposing, bringing awareness to, and possibly correcting social injustices. It is ironic, however, that the ideology permeating the literature surrounding 
transformative learning and critical theory is that critical theory and transformative learning inherently leads to good and positive outcomes. There is some emerging literature challenging this view. Taylor and Cranton (2013) point out the apparent lack of application of critical reflection to transformative learning itself and urge that the principles of critical thinking and critique so central to transformative learning should be applied to the itself to challenge the 'intrinsic goodness of human beings' upon which the theory is based. Likewise, Naughton and Schied (2010) challenge the basis that 'humans are inherently good and thus transformative learning is always a positive outcome' through their discussion of the "dark side of transformative learning" (p. 1). Although transformation and change of perspective genuinely occurs, the path the individual subsequently follows is outside of what is "good". By Mezirow's own admission, the theory of transformation is based on the assumption of the "perfectibility of human beings" (2000, p. 9). It is important to realize that critical theory and transformative learning can both be seen as rooted in the ideals of humanism, which is founded on the notion that human beings are intrinsically good. Beyond the awareness of transformative learning as having the potential to derail towards increasing rather than decreasing human misery, there are other considerations of an ethical nature, which must be brought to the fore in discussing critical theory and in particular transformative learning. As Butterwick and Lawrence (2009) contend, as educators, we can "create an environment where transformative learning can occur; however, without care and attention to the power we have...we can contribute to oppression and silencing (p. 44).

There are of course the potential negative consequences of great personal change. As social theories uphold, all individuals are situated in a society and have interaction and relationships with others. Focusing in for a moment on one example of social theory - activity 
theory (grounded in the work of Vygotsky, Lont'ev and others) helps clarify other risk for the individual associated with undergoing transformative leaning and subsequent change. Activity theory purports the activity of individuals is mediated by tools, as well as the community and the rules and norms of the group. Rules and norms and other shared assumptions are the threads that bind people together and create a sense of community and belonging. In transforming their perspective individuals may risk severing those bounding threads. Occurring at a widespread level throughout a society or culture, the severing of common threads of assumption may, at worst, destabilize society. Furthermore, it is the common threads and unspoken assumptions within a society that provide a sense of coherence and continuity to its members. From this perspective then, some may argue that there are ethical considerations in implementing transformative learning, even at the level of simply asking individuals to self-examine their own beliefs (Taylor \& Cranton, 2013). Such potential negative consequences have been raised in literature by various authors including Berger (2004), Brookfield (1994) and Hoggan, Mlkki and Finnegan (2017).

Generally, though, the potential for negative consequence remains largely neglected in most literature surrounding implementation of transformative learning and critical theory. As educators it is necessary to raise awareness of potential impacts and the risks that may arise from activity designed to foster critical thinking, reflection and ultimately transformation (Hoggan, Mlkki, \& Finnegan (2017). It is well to add to one's understanding of transformative learning that the process of transformative learning is one characterized by tensions between stability and instability, between the individual and the collective, and between coherence and continuity.

\section{Conclusion}


There has been increasing interest in the theory of transformative learning, as it is more commonly referred to the United States in the field of adult education, since Mezirow (1978a) proposed it based on his research and his interpretation of Habermasian critical theory. Over the years many articles, books (Cranton, 1994; King, 2005; Mezirow, 1990, 1991, 1997; Mezirow, 2000), journals, and even conferences (for example, The International Transformative Learning Conference 1998-2005) have examined, critiqued, and further developed this theory. These research endeavors, publications and venues have emerged mostly with in the field of adult education in order to provide a forum for detailed analysis of this prevalent theory and to demonstrate how this theory has affected the course of adult learning practices (Merriam \& Caffarella, 1999).

However, at the same time there is some concern that transformative learning has focused too much on a rational perspective (Dirkx, 1997), a western perspective (King, 2005), and too narrowly within the formal field of adult education alone (King, 2004). Indeed, the discussion in Canada (O’Sullivan, 2001; O’Sullivan, Morrell \& O’Connor, 2002) and Europe (Jarvis, 1987) focused on different issues within transformative learning than in the United States. Some are raising ethical concerns over critical theory and others are encouraging greater acknowledgement of trajectories of transformative learning that takes people outside the bounds of what is 'good'.

We have sought to extract the essence of critical theory and transformational learning, emphasizing commonality and uniqueness of the two theories, and discussing connections and possibilities in adult learning. We have to some extent challenged the ideology of transformative learning necessarily leading to positive outcomes and have drawn attention to the risks (and potential ethical questions) posed by transformative learning. It is hoped our work will incite 
Critical Theory and Transformative Learning 20

further discussion and prompt ongoing critical analysis as a vehicle for further understanding and perhaps evolution of these two seminal theories. 


\section{REFERENCES}

Adorno, T.W. (1973). Negative dialectics. New York, NY: Seabury Press.

Armitage, A. (2010). From sentimentalism toward a critical HRD pedagogy. Journal of European Industrial Training, 34(8/9), 735-752.

Bamber, P., \& Hankin, L. (2011). Transformative service learning: No passport required. Education and Training, 53(2/3), 190-206.

Bandura, A. (2002). Selective moral disengagement in the exercise of moral agency. Journal of Moral Education, 31(2), 101-119.

Baumgartner, L. M. (2001). An update on transformational learning. New Directions for Adult and Cointinuing Education, 89, 15-24.

Berger, J. G. (2004). Dancing on the threshold of meaning: Recognizing and under- standing the growing edge. Journal of Transformative Education, 2, 336-351.

Bradley-Levine, J., \& Carr, K. A. (2015). Critical theory and Catholic social teaching: A research framework for Catholic schools. Journal of Catholic Education, 18(2), 27-43.

Brookfield, S. (2001). Repositioning ideology critique in a critical theory of education. Adult Education Quarterly, 52(1), 7-22.

Brookfield, S.D. (2005). The power of critical theory: Liberating adult learning and teaching. San Francisco, CA: Jossey-Bass.

Brookfield, S. D., Kalliath, T., \& Laiken, M. (2006). Exploring the connections between adult and management education. Journal of Management Education, 30(6), 828-839.

Buber, M. (1958). I and thou (Trans., R. G. Smith). New York, NY: Scribner. 
Butterwick, S., \& Lawrence, R. (2009). Creating alternative realities: Arts based approaches to transformative learning. In J. Mezirow, E. Taylor, \& Associates (Eds.), Transformative learning in practice: Insights from community, workplace, and higher education (pp. 3545). San Francisco, CA: Jossey-Bass.

Carr, A. N. (2005). The challenge of critical theory for those in organization theory and behavior: An overview. International Journal of Organizational Theory and Behavior, 8(4), 466494.

Chih, W., \& Huang, L. (2016). Prior knowledge, transformative learning and performance. Industrial Management \& Data Systems, 116(1), 103-121.

Cotton, G. (2017). The role of authentic communication in moral development and transformative education. Journal of Thought, 51(1), 47-64.

Cranton, P. (1994). Understanding and promoting transformative learning: A guide for educators of adults. San Francisco, CA: Jossey-Bass.

Cranton, P. (2002). Teaching for transformation. New Directions for Adult and Continuing Education, 93, 63-72.

Cranton, P. (2016). Understanding and promoting transformative learning: A guide to theory and practice. Sterling, VA: Stylus Publishing.

Cranton, P., \& Taylor, E. (2012). Transformative learning theory: Seeking a more unified theory. In E. Taylor, P. Cranton \& Associates (Eds.) The handbook of transformative learning theory: Theory, research and practice (pp. 3-20). San Francisco, CA: JosseyBass. 
Deneys-Tunney, A. (2012). Rousseau shows us that there is a way to break the chains-from within. Retrieved from https://www.theguardian.com/commentisfree/2012/jul/15/rousseau-shows-us-way-breakchains

Denzin, N. K., \& Lincoln, Y. S. (2011). Preface. In N, K. Denzin \& Y. S. Lincoln (Eds.), The Sage handbook of qualitative research (pp. ix-xvi). Thousand Oaks, CA: Sage.

Dirkx, J. (1997). Nurturing the soul in adult learning. In P. Cranton (Ed.), Transformative learning in action. New Directions in Adult and Continuing Education, 74, 79-88.

Taylor, E., \& Cranton, P. (2013). A theory in progress. Issues in transformative learning theory. European journal for Research on the Education and Learning of Adults, 4(1), 33-47.

Gibbs, J., Rozaidi, N., \& Eisenberg, J. (2013). Overcoming the “ideology of openness'”: Probing the affordances of social media for organizational knowledge sharing. Journal of Computer-Mediated Communication, 19, 102-120.

Gaudelli, W. (2008). Critical pedagogy as alternative crisis curriculum. In J. Diem \& R. J. Heifenbein (Eds.), Unsettling beliefs: Teaching theory to teachers (pp. 75-86). Charlotte, NC: Information Age Publishing, Inc.

Geuss, R. (1981). The idea of critical theory: Habermas and the Frankfort School. Cambridge, MA: Cambridge University.

Greene, M. (1995). Releasing the imagination. San Francisco, CA: Jossey-Bass.

Harvey, J. B. (1988). The Abilene paradox: The management of agreement. Organizational Dynamics, 3(1), 63-80.

Hoggan, C., Malkki, K., \& Finnegan, F. (2017). Developing the theory of perspective transformation: continuity, intersubjectivity, and emancipatory praxis. Adult Education 
Quarterly, 67(1), 48-64.

Horkheimer, M. (1974). Eclipse of reason. New York, NY: Continuum.

Horkheimer, M. (1995). Critical theory: Selected essays. New York, NY: Continuum.

Horkeheimer, M. (1976). Traditional and critical theory. In P. Connerton (Ed.), Critical sociology: Selected readings (pp. 206-224). Harmondsworth, England: Penguin. (Original work published in German 1937).

Hullender, R., Hinck, S., Wood-Nartker, J., Burton, T., \& Bowlby, S. (2015). Evidences of transformative learning in service-learning reflections. Journal of the Scholarship of Teaching and Learning, 15(4), 58-82.

Jarvis, P. (1987). Adult learning in the social context. New York, NY: Croom Helm.

Kilgore, D.W. (2001). Critical and postmodern perspectives on adult learning. New Directions for Adult and Continuing Education, 89, 53-61.

Kincheloe, J. L. (2004). Into the great wide open: Introducing critical thinking. In D. K. Weil \& J. L. Kincheloe (Eds.), Critical thinking and learning: An encyclopedia for parents and teachers (pp. 1-51). Westport, CT: Greenwood Press.

Kincheloe, J. L. (2008). Critical theory and critical pedagogy today. Studies in Philosophy and Education, 27(5), 399-404.

Kincheloe, J. L., McLaren, P., \& Steinberg, S. R. (2011). Critical pedagogy and qualitative research: Moving to the bricolage. In N. K., Denzin \& Y. S. Lincoln (Eds.). The Sage handbook of qualitative research (pp. 163-178). Thousand Oaks, CA: Sage.

King, K. P. (2004). Transformative learning. In S. Farmer \& S. Stein (Eds.), Connotative learning (pp. 195-206). Washington DC: IACET.

King, K. P. (2005). Bringing transformative learning to life. Malabar FL: Krieger. 
Liston, D. P. (2008). Critical pedagogy and attentive love. Studies in Philosophy and Education, 27(5), 387-392.

Marcuse, H. (1964). One dimensional man. Boston, MA: Beacon.

Merriam, S. B., \& Caffarella, R. (1999). Learning in adulthood. San Francisco: Jossey-Bass.

Mezirow, J. (1978a). Education for perspective transformation; Women's re-entry programs in community colleges. New York, NY: Teacher's College, Columbia University.

Mezirow, J. (1978b). Perspective transformation. Adult Education Quarterly, 28(2), 100-110.

Mezirow, J. (1981). A critical theory of adult learning and education. Adult Education, 32(1), 324.

Mezirow, J. (1988). On Critical reflection. Adult Education Quarterly, 3, 185-198.

Mezirow, J. (1990). Fostering critical reflection in adulthood: A guide to transformative and emancipatory learning. San Francisco, CA: Jossey-Bass.

Mezirow, J. (1991). Transformative dimensions of adult learning. San Francisco, CA: JosseyBass.

Mezirow, J. (1995). "Transformation theory of adult learning." In M. R. Welton (Ed.), In defense of the lifeworld (pp. 39-70.). New York, NY: SUNY Press.

Mezirow, J. (1997). Transformative learning: Theory to practice. In P. Cranton (Ed.). Transformative learning in action. New Directions in Adult and Continuing Education, $74,5-12$.

Mezirow, J. (Ed.). (2000). Learning as transformation: Critical perspectives on a theory in progress. San Francisco, CA: Jossey-Bass.

Morgan, W. J., \& Guilherme, A. (2012). I and Thou: The educational lessons of Martin Buber's dialogue with the conflicts of his times. Educational Philosophy and Theory, 44(9), 979996. 
New York Times. (2017, Oct 30). Russian Influence Reached 126 Million Through Facebook Alone. Retrieved from https://www.nytimes.com/2017/10/30/technology/facebookgoogle-russia.html

Nichols, R. G., \& Allen-Brown, V. (1996). Critical theory and educational technology. In D. H. Jonassen (Ed.), Handbook of research for educational communications and technology (pp. 226-252). New York, NY: Simon \& Schuster Macmillan.

O'Sullivan E. (2001). Transformative learning: educational vision for the $21^{\text {st }}$ century. London, UK: Zed.

O’Sullivan, E., Morrell, A. \& O'Connor, M. (2002). Expanding the boundaries of transformative learning. New York, NY: Palgrave MacMillan.

Rosebrough, T. R., \& Leverett, R. G. (2011). Transformational teaching in the information age: Making why and how we teach relevant to students. Alexandria, VA: ASTD.

Ryman, S., \& Richardson, B. (2010). Creating and sustaining online learning communities: Designing environments for transformative learning: Part II: Sustaining a learning community through constructive controversy. International Journal of Pedagogies \& Learning, 5(3), 46-58.

Sessa, V. I., London, M., Pingor, C., Gullu, B., \& Patel, J. (2011). Adaptive, generative, and transformative learning in project teams. Team Performance Management, 17(3/4), 146167.

Taylor, E. W., \& Snyder, M. (2012). A critical review of research on transformative learning theory, 2006-2010. In E. Taylor \& P. Cranton (Eds.), The handbook of transformative 
learning: Theory, research, and practice (pp. 37-55). San Francisco, CA: JosseyBass.

Watson, S. L., \& Watson, W. R. (2011). Critical emancipatory and pluralistic research for education: A review of the critical systems theory. Journal of Thought, 46(3/4), 63-77.

Weil, D. (2004). Values and dispositions of critical thinking: Developing habits of mind as moral commitments to thought. In D. K. Weil \& J. L. Kincheloe (Eds.), Critical thinking and learning: An encyclopedia for parents and teachers (pp. 485-490). Westport, CT: Greenwood Press. 